\title{
Better Social Welfare, Ukraine
}

\author{
Marc P. Berenson*
}

\begin{abstract}
To a large extent, the recent global economic-financial crisis has not affected how the social welfare system in Ukraine provides assistance. While Ukraine did contribute more funds to help meet the greater demands for assistance during the crisis, the country did not maintain the value of social benefits in real terms (after discounting inflationary effects), and it introduced new eligibility qualifications that restricted the numbers of those able to apply for unemployment assistance, thereby easing the burden on the state. All in all, the crisis did not change the way politics is done in Ukraine, nor did it change the fact that the relatively passive and nascent civil society has remained largely inclined to let the state carry on developing and implementing social welfare policy in the same way as before. As such, acceptance and avoidance of the state largely has become the norm.
\end{abstract}

\section{Introduction}

Has the recent global economic-financial crisis affected how the social welfare system in Ukraine provides assistance? To a large extent, the answer emerging from the roundtable discussion on 'The Global Financial-Economic Crisis and the Politics of Employment and Social Defence of Ukraine' in Kyiv in May 2010, is 'No'. Ukraine has weathered the crisis fairly well, being able to respond to increased demands during the crisis period, contributing more funds and increased benefit amounts in nominal terms, but the real value of benefits (due to inflation) were not sustained and new regulations regarding qualifications with respect to who is eligible to receive unemployment assistance, moderated the obligations of the state. The crisis did not change the way politics is done in Ukraine, nor did it change the fact that the relatively passive and nascent civil society - which has seen years of deeply entrenched political conflict freeze out chances for overwhelming policy changes - has remained largely inclined to let the state carry on developing and implementing social welfare policy in the same way as before. As such, acceptance and avoidance of the state has largely become the norm, with little interest on the part of society to challenge the ways in which policy is legislated and implemented.

\section{Methodology}

The central question as to how the recent global economic-financial crisis has affected Ukraine's social welfare system was addressed at the roundtable by a variety of different stakeholders on the issue of social welfare provision - those who work in the relevant Ministry of Labour and Social Policy, those who work at lower levels of the system and legislators who write and amend social welfare policy, NGO members who represent citizens who receive assistance from the state, as well as local academic and other professional experts. The roundtable - which was organised around the session themes: 'Basic tasks of social policy after the 2010 presidential elections'; 'Social defence of the population of Ukraine in the conditions of the crisis'; 'The state of the most impressionable population groups during the crisis'; 'Research of the state of the social welfare system in Ukraine' and 'Prospects of development of the system of the public welfare at Ukraine and collaboration between the international, Ukrainian and governmental researchers' - succeeded in answering all four questions (see below) of the Reimagining Development initiative with respect to this site.

\section{How has the recent global economic-financial crisis impacted the lives and livelihoods in Ukraine?} This question was addressed in two parts. First: How has the recent global economic-financial crisis impacted the lives and livelihoods of Ukrainians? And: Do any groups lose out in a downturn, coupled with declining tax revenues and greater demands for social welfare support? 
Second: How has the recent global economicfinancial crisis affected how the social welfare system in Ukraine provides assistance? In particular, the questions raised were concerned with whether the state has become more or less responsive to citizen needs and what drives that whether citizens were less able to claim benefits and ultimately, how stable was the social welfare system in 2009 and what provided for that stability.

With respect to how the crisis affected Ukrainians, it is important to recognise that Ukraine is a lower-middle-income country (according to the World Bank), which saw a dramatic drop in GDP of 15 per cent in 2009 (the largest decline for a European country of its population size). This crisis affected two groups of Ukrainians in particular. First, those whose income was dependent on social benefits, became the most vulnerable. However, the new and nascent post-Soviet middle class, who took out newly available loans to purchase cars and real estate, also became very vulnerable, especially those who became unemployed and were unable to pay back their loans. For those receiving assistance, Labour and Social Policy Deputy Minister, Victor Ivankevich, observed that the payment of pensions and social benefits increased in nominal terms, but fell in real terms. The government paid for social assistance, not taking into account inflation, the social standards of living wage and the minimum wage.

Meanwhile, the Ministry's Director of the Department in Charge of Matters Regarding Elderly People, S.M. Ustimenko, regarded the elderly to have suffered the most from the crisis, as the purchasing power of their pensions went down substantially, as did that of the middle classes, who could not meet their consumer credit obligations, which was alleviated only by government measures taken against the banks.

With respect to the second set of issues pertaining to how the recent global economic-financial crisis affected how the social welfare system in Ukraine provides assistance, Ukraine's obligatory state insurance system worked without failure in the crisis conditions, according to Deputy Minister, Ivankevich. Noteworthy, however, was the fact that income into the system decreased, especially as the government made the extraordinary step of releasing some state enterprises in the coal industry from their tax obligations - something that is not to be considered admissible in the future, as it created large deficits in the pension and industrial accident insurance funds, the former of which had to receive payments from the state budget to help.

Anti-crisis policies were focused most specifically on the rising unemployed throughout 2009.

Unemployment benefits increased, but at the same time, the conditions became harder. Thus, the benefit amount increased by 1.8 per cent compared to 2008. At the beginning of the crisis, unemployment was 6.4 per cent. After three months of the crisis, the level reached 9.5 per cent, and today it is 7.8 per cent. (As a reflection, unemployment in May 2010 stood at 9.3 per cent in the USA, which has been out of the recession for many months.) According to the Deputy Minister, national and international experts have predicted that to reach pre-crisis levels of unemployment in Ukraine, two to three years are needed. Meanwhile, the crisis had an interesting side effect, by which fewer job vacancies caused those already employed to be very keen to avoid being dismissed. As such, the number of redundancies decreased by three times in Ukraine at the beginning of 2009.

Anti-crisis measures in the labour market have been fairly effective, in part, because of the increase in unemployment benefit payments, but also because stricter rules for being able to register as unemployed have been adopted, after being introduced by parliament at the end of 2008. The International Labour Organization (ILO) convention, for example, provided Ukraine with a clear definition of the unemployed people who are looking for work and ready to accept vacancies. As such, if a person is registered in the employment service and is offered a job twice, but he/she refuses, this person becomes ineligible for services for a time. A further new rule required weekly visits to the employment service, which also significantly reduced registered unemployment in rural areas, as people who were really self-employed did not have time to visit the employment services. Thus, the number of 'unofficial unemployed' sharply increased to 2.5 million, and the government has not yet determined how to serve this segment of the population.

Impoverished families saw their benefits increased by an average on 48 per cent, according 
to the Director of the Department of Social Protection at the Ministry, N. Ryazanova. Nowadays, Social Security is implemented through the execution of more than 15 programmes related to vulnerable groups, such as foster children, children being brought up by single parents, children whose parents evade paying child support and low-income housing programme subsidies. From among the 17.5 million families in Ukraine, these programmes cover more than 3 million families. In 2009, 15 billion Ukraine hryvnia (UAH) were streamed into social benefits and in 2010, more than 24 billion was allocated. Increases in benefits were to have occurred three times in 2010.

\section{How has the recent global economic-financial crisis impacted values, relationships, ideas, methods and/or behaviours?}

At the domestic level, the short answer here appears to be 'not much'. Ukraine is characterised by an overwhelmingly passive population and nascent civil society, which rose up in late 2004 to stage the Orange Revolution in an effort to change the way politics is organised in the country, only to endure five more years of a bitter intraelite political conflict that failed in the eyes of many citizens to change the way citizens fundamentally interact with their state. Attention has been given in the media and by civil society groups on other more critical topics related to domestic and international politics, especially concerning elites and elections. Given the overexhaustion from long-drawn-out electoral campaigns and elite infighting, 'Social Welfare' is not a 'hot topic' in Kyiv at present for the media, NGOs or civil society at large. In short, as the Ministry's Director of the Department in Charge of Matters Regarding Elderly People, S.M. Ustimenko, put it, 'The question has not been decided regarding wide engagement in the system by public organisations and social businessmen'.

However, some new measures were undertaken with the 'usual suspects' of parliament, the Ministry of Labour and Social Policy, trade unions and others. For example, the crisis has further brought to the floor the issue of misuse of the social welfare system, especially regarding unemployment services and benefits. Many work illegally, but still register as being unemployed to obtain benefits. For example, builders from western Ukraine come to work in Kyiv but are registered with the employment service back home. As Deputy Minister Ivankevich mused, 'I do not know how they organise this. There are ways to combat this phenomenon'. As a response, new regulations were developed, initiated by the Ministry of Labour and Social Policy, to limit illegal employment in the labour market. There were two rounds of brainstorming, in which the trade unions, employers, employment service and other stakeholders took part. The regulations included schemes of interaction between the Ministry, employment services, tax services, inspection of employment, inspection of work and other structures that could take part in the process of legalisation of employment.

With respect to other fraud regarding other social benefits, the Institution of Social Inspectors tries to control the problem. There are two inspectors in each region and four in each district. 'Frankly speaking, it is not enough for the whole country', stated Ryazanova. They were formed within a programme to improve the development of the state, but later, the responsibility to control fake documents was added in as an extra function.

\section{How has the recent global economic-financial crisis impacted the types of changes that people would like to see?}

The crisis has yet again raised the issue regarding the fact that the social welfare system in Ukraine - as in many other post-communist states - is not needs-based and should be better targeted towards the poor. And, the Ministry is deemed to be scarcely capable of meeting social obligations based on the defined set of social living standards.

With respect to childcare benefits, the Ministry is trying to balance the goals of the European Social Charter (revised) that indicate that assistance for children less than three years old should not be a priority for the government, which should encourage women to return to work, and other efforts that the trade unions and the Ministry of Finances are making to agree upon a sustainable minimum level of income. 'They both are right to some extent', stated Ryazanova. This raises the issue as to what should be the standard starting point for 'minimum' or 'liveable' income levels in Ukraine - as Ryazanova argued that it is not effective to use the system of subsistence level as a starting point for all standards in Ukraine. 
In addition, the state has begun to reduce or limit social assistance for categories of privileges that are not targeted specifically at the poor. These are privilege categories such as those who were victims of the Chernobyl disaster; those who served in the military or were children of war, as well as other general transport and municipal privileges - in short, categories of privileges where income is not checked.

Natalya Pilipiv and Tanya Khorvat from the Centre for Social Partnership and Lobbying at the Kyiv Mohyla Academy also emphasised the need for the decentralisation of the system of social services and for a strengthening of the authorities of local organs as ways to help address some of these targeting issues.

\section{How has the recent global economic-financial crisis impacted the recommendations on specific assignable actions to enable change to happen?}

Again, as stated above, the crisis has not dramatically altered the manner in which actors - foreign and domestic - come together to address Ukraine's social welfare needs. But, at the international level, cooperation is continuing, albeit much in the same vein as before. For example, collaboration is now being conducted with such international organisations as the ILO and the International Organization (IOM) for Migration, in the areas of bilateral and multilateral agreements on employment, particularly mutual adjustment of conditions of employment, migration, investment and education. International technical assistance is also still welcome in many areas.

\section{Note}

* On 25 May 2010, the Ministry of Labour and Social Policy of Ukraine; the Foundation for Safe Society, Ukraine; Dim Svobodi (Freedom House Ukraine); and the Institute of Development Studies (IDS) co-sponsored the roundtable, 'The Global Financial-Economic Crisis and the Politics of Employment and Social Defence of Ukraine', held at the Ministry's seminar hall in Kyiv. Among the participants were: Deputy Minister of Labour and Social Policy, Victor Ivankevich; I. Salmina of the Department of Social Defence; Director

\section{Social politics 'as usual' in Ukraine}

For the outside observer, it might seem quite odd that a massive economic shock, resulting in a massive decline of 15 per cent in GDP, would appear to have little consequence for the politics or social policies of a lower-middle-income country. However, Ukrainians, who once took to the streets in large numbers to protest against electoral fraud during the 2004 Orange Revolution, have failed largely to press the government to reform its social welfare policies. The reasons for this are numerous, but can be deemed to be 'usual' for Ukraine, given its unique path. First, the drop in GDP in 2009 was far less than the more dramatic decline in economic growth in the 1990s, when GDP in 1999 comprised about half of the country's preindependence level. As such, the global financial crisis paled in comparison to the relatively recent economic problems in the country, which also were not accompanied by any major social pressures for policy change at the time. Second, the Ukrainian state, in anticipation of the 2010 presidential elections, also did increase funding for social welfare, while it buckled down on the requirements for obtaining benefits. Third, the prolonged and entrenched political elite conflict that continued despite the Orange Revolution has made the Ukrainian public even more weary of trying to change the state, as well as more cognisant of the need to rely on themselves even more. Finally, the relatively southern location of the country coupled with the availability of private garden plots and other local survival skills, honed through more severe and recent economic difficulties, should not be discounted as being beneficial to Ukrainians who expect less from their state.

of the Department in Charge of Matters Regarding Elderly People, S.M. Ustimenko; Director of the Department of Social Protection, N. Ryazanova; Freedom House Ukraine President, Svetlana Franchuk; the Foundation for Safe Society's Sergei Panzer; Natalya Pilipiv and Tanya Khorvat, Centre for Social Partnership and Lobbying at Kyiv Mohyla Academy; Marc Berenson of IDS and local social welfare workers from Kyiv. Presentational material was provided by T. Morgun, editor of Trade Unions of Ukraine. 